\title{
Effectiveness of Aerator Ventures, Deposition with Magnets, Filtering, and lon Exchange in One Unit against Reduction of Iron, Total Dissolved Solid, and Marine Well Water
}

\author{
Dwi Sudiarto $^{1 *}$, Nurhayati Nurhayati ${ }^{2}$, Fajriansyah Fajriansyah $^{1}$ \\ ${ }^{1}$ Department of Environmental Health, Polytechnic of Health, Ministry of Health, Aceh, Indonesia; ${ }^{2}$ Department of Nursing, \\ Polytechnic of Health, Ministry of Health, Aceh, Indonesia
}

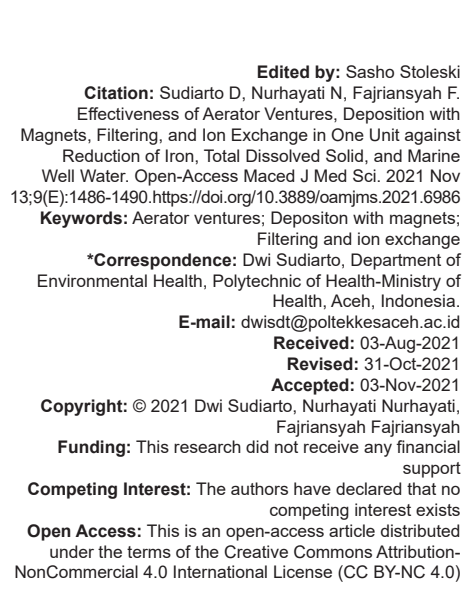

\section{Introduction}

Indonesia's potential for water resources is very abundant, around 3200 billion $\mathrm{m}^{3} /$ year spread over 7956 rivers and 521 lakes, continuous water availability of around 700 billion $\mathrm{m}^{3} /$ year makes Indonesia one of the wettest countries in the world [1]. With advances in technology and industrial growth, freshwater resources around the world are under threat. One-sixth of the world's population suffers from a situation of unavailability of freshwater [2]. There are still more than 90 million people in Indonesia who still find it difficult to access clean water with uneven water availability both spatially and temporally throughout the year so that in one area, there are droughts in the dry season and floods in the rainy season [3]. Changes in land use from vegetated areas to build areas have disrupted the ecological balance of the city, one of which is groundwater quality. Groundwater quality is currently vulnerable to contaminants from natural and human activities [4]. Today, indiscriminate and uncontrolled discharge of metal contaminated industrial effluents into the environment has become an issue of major concern. Heavy metals, being nonbiodegradable and persistent beyond a permissible concentration, form unspecific compounds inside the cells, thereby causing cellular toxicity. The only alternative to remove them from the wastewater is by immobilizing them. The conventional methods adopted earlier for this purpose included chemical precipitation, oxidation, reduction, filtration, electrochemical treatment, evaporation, adsorption, and ion exchange resins. In almost all areas in Indonesia, groundwater contains relatively high levels of iron ( $\mathrm{Fe}$ ) and manganese ( $\mathrm{Mn})$.

Among the many contaminants, $\mathrm{Fe}$ and $\mathrm{Mn}$ are present in chemicals originating from both natural sources, such as soil and rock, and human activities, such as industrial waste and overexploitation of groundwater, and can eventually pollute groundwater [5], [6]. Extraction of groundwater can produce unwanted reddish-brown $\mathrm{Fe}$ and $\mathrm{Mn}$ deposits. This metal can also accumulate in piping systems and cause scaling [7], [8]. Its deposition in the pipe reduces the pressure of the water flow and 
eventually damages the pipe. Several studies have noted that adverse non-carcinogenic problems, such as nervous system disorders, respiratory, neurological, and digestive problems, especially in adults, can arise from the consumption of $\mathrm{Fe}$ and $\mathrm{Mn}$ [9], [10]. Groundwater moving through sedimentary rocks and soil can pick up a wide variety of compounds, such as magnesium, calcium, chloride, arsenate, fluoride, nitrate, and $\mathrm{Fe}$; thus, the effects of these natural contaminants depend on their type and concentration. Natural elements present at unacceptable levels can contaminate water [11], [12], [13]. The increase in Mn levels in groundwater is a concern and requires further investigation [15]. For people who live in coastal areas or where the soil contains high minerals, most of the water dug wells in the area are brackish. Brackish water or brackish water is water that has a salinity between $0.5 \mathrm{ppt}$ and $17 \mathrm{ppt}$.

In comparison, freshwater has a salinity of fewer than $0.5 \mathrm{ppt}$ and maximum drinking water of 0.2 ppt. Brackish water contains relatively high sodium and chloride as well as $\mathrm{Ca}$ and $\mathrm{Mg}$, which cause hardness. Brackish water is one of the sources of water that humans cannot use directly for daily needs. Therefore, it is necessary to treat it first to reduce the number of minerals or salt content. Most of the water from the wells dug in the area is brackish for people who live in coastal areas or the land containing mineral water. Brackish water or brackish water is water that has a salinity between $0.5 \mathrm{ppt}$ and $17 \mathrm{ppt}$.

In comparison, freshwater has a salinity of fewer than $0.5 \mathrm{ppt}$ and maximum drinking water of 0.2 ppt. Brackish water contains relatively high sodium and chloride as well as $\mathrm{Ca}$ and $\mathrm{Mg}$, which cause hardness. Brackish water is one of the sources of water that humans cannot use directly for daily needs. Therefore, it is necessary to treat it first to reduce the number of minerals or salt content. The presence of $\mathrm{Fe}$ in groundwater shows significant seasonal fluctuations and may be influenced by changes in environmental conditions in the aquifer.

There are various kinds of clean water treatment techniques that we can use, including coagulation, filtration, sedimentation, aeration, and ion exchange, all of which can be applied in simple water treatment in housing. Based on this background, researchers are interested in integrating clean water treatment techniques, namely, venturi aerators, magnetic deposition, filtration, and ion exchangers, to obtain clean water and meet health requirements. The novelty of this research is that using modification techniques to remove heavy metals have been critically analyzed by mixing aerator ventures, deposition with magnets, filtering, and ion exchange in one unit against reduction of $\mathrm{Fe}$.

\section{Methods}

This research is included in the quasi-experimental design research. With time series design in this design, the groups used for research cannot be selected randomly. The group was given a pretest up to 4 times to determine the stability and clarity of the group's condition before being given treatment. If the pretest results 4 times have different values, it means that the group is not consistent. After the stability of the group's condition can be identified, then the treatment is given. This research design uses only one group, so it does not require a control group. The population in this study was all water containing $\mathrm{Fe}$ and $C L$ in the Darul Kamal sub-district, Aceh Besar. The sample in this study is part of the population following research needs. Calculation of the sample size is calculated by the Federer formula as follows:

$$
\begin{gathered}
(\mathrm{t}-1)(\mathrm{n}-1) \geq 15 \\
(5-1)(\mathrm{n}-1) \geq 15 \\
4 \mathrm{n}-4 \geq 15 \\
4 \mathrm{n} \geq 19 \\
\mathrm{n} \geq 4.75 \sim 5 \\
\text { Information: } \\
\mathrm{t}: \text { Number of test groups } \\
\mathrm{n}: \text { Sample size per group }
\end{gathered}
$$

The ideal sample size according to the Federer formula above is 5 times or more. Thus, the total number of all test groups is 25 times. The research plan begins with the preparation of tools and materials, treatment, and inspection of the content of Fe, TDS, and $\mathrm{CL}$. The implementation is carried out by making a series of unit filter equipment consisting of 4 venturi aerators, sedimentation pipes, pressurized water filters, stop faucets according to the needs and sizes of pipes, installing bar magnets, water pumping machines, cation resin pipes, anion resin pipes, and experiment drawing plan. Data analysis was preceded by grouping univariate data from each variable; then, bivariate table data were made and analyzed using statistical tools using bivariate and multivariate techniques.

\section{Results and Discussion}

\section{FE parameters}

The Fe content in drilled healthy water before treatment is known to be an average of $3.13 \mathrm{mg} / \mathrm{L}$ as shown in Table 1; according to the Minister of Health Regulation No. 32 of 2017 concerning Environmental Health Quality Standards and Water Health 
Table 1: One-way ANOVA test results for Fe content in each treatment in a venturi aerator, precipitation with magnets, filtration, and ion exchange in one unit

\begin{tabular}{llllll}
\hline Fe analysis results & Sum of squares & df & Squares mean & $\mathrm{F}$ & Sig. \\
\hline Value between groups & 96.267 & 7 & 13.752 & 426.457 & 0.000 \\
Value in groups & 2.064 & 64 & 0.032 & & \\
Total number & 98.331 & 71 & & & \\
\hline
\end{tabular}

Requirements for Sanitary Hygiene purposes, it does not meet the condition.

The results of this one-way ANOVA test show that there is a difference in each treatment in general. Each treatment given has the effect of decreasing the Fe content and the end of the content treatment. Judging from each treatment in the venturi aerator, deposition with magnets, filtering sea sand, and anion and cation resins in one unit showed a decrease; it was seen that the more treatment was added, the lower the Fe content.

The significant value is 0.00 ; this means a significant difference in the results of various $\mathrm{Fe}$ examinations from various treatments. Moreover, to find out in more detail the differences between treatments, the least significant difference (LSD) test was continued. The results of the LSD test showed that there was a significant difference between all treatments. This proves that the treatment given has a significant effect in reducing the Fe content.

The effect of treatment on the decrease in Fe content show that the decrease in Fe content was initially an average of $7.9 \%$, namely, with the venturi aerator treatment until the end of the treatment, the average decrease was up to $95 \%$, which is a combination of starting from venturi aerator until the treatment using a second cation resin. This decrease proves that the theory of oxygen can cause aeration, which will convert $\mathrm{Fe} 2+$ ions into $\mathrm{Fe} 3+$. This $\mathrm{Fe} 3+$ ion will precipitate so that it will reduce the solubility of $\mathrm{Fe}$ in the water. Likewise about this venturi aerator, namely, according to Bernoulli's principle, the fluid pressure in a narrow section of the pipe is smaller if the fluid flow rate is excellent. Because the fluid is entering and leaving the same, the fluid pressure becomes negligible if the fluid flow rate is high. The pressure on the venturi neck is low from environmental pressure, which is the key to this technology where air can enter the venturi through holes in the venturi neck. The presence of a magnet also assists this deposition. With this magnet, the ions attracted by a magnet will quickly be separated from those whose forces are opposite to those of the magnet. Like the theory, magnets are objects of Fe that can attract other metals or ions that have the nature of attraction or repulsion to ions that are opposite or the same. Magnets have different north and south poles; these two poles will cause a reaction that repels each other when they are brought close to a similar pole, whereas when they are brought close to a different pole, they will attract each other. The addition of treatment by settling for a longer time does not have a significant effect; the ability to decrease up to a maximum of $97 \%$ (Table 2) and the average reaches a decrease in $30 \mathrm{~h}$ of precipitation of the two treatments, the first without any precipitation and with the addition of the time of deposition that this tool is very effective for reducing $\mathrm{Fe}$ content.

Table 2: Test results for one-way ANOVA reduction on the percentage of $\mathrm{Fe}$ reduction in venturi aerator equipment, precipitation with magnets, filtering, and ion exchange in one unit

\begin{tabular}{llllll}
\hline $\begin{array}{l}\text { Result of reduction of } \\
\text { treatment for Fe }\end{array}$ & sum of squares & Df & Square mean & $\mathrm{F}$ & Sig. \\
\hline Value between groups & 98158.234 & 7 & 14022.605 & 426.687 & 0.000 \\
Value in groups & 2103.292 & 64 & 32.864 & & \\
Total & $100,261.526$ & 71 & & & \\
\hline
\end{tabular}

\section{TDS parameters}

The TDS parameter shows that the TDS content tends not to decrease until the end of the treatment using anion and cation resins. This TDS content appears to decrease in the venturi aerator treatment with an average decrease of $0.05 \%$. The results of the one-way ANOVA test in Table 3 as a whole show a significant difference between one treatment and another.

Table 3: ANOVA test for decreasing TDS content in the venturi aerator, deposition with magnets, filtering sea sand, as well as anion and cation resins

\begin{tabular}{llllll}
\hline $\begin{array}{l}\text { Result of treatment } \\
\text { reduction for TDS }\end{array}$ & Sum of square & df & Square mean & F & Sig. \\
\hline Value between groups & 5.548 & 7 & 0.793 & 8.361 & 0.000 \\
Value in groups & 6.067 & 64 & 0.095 & & \\
Total & 11.614 & 71 & & & \\
\hline
\end{tabular}

The results of the LSD test showed no difference between before treatment and after aeration using a venturi aerator, although the calculations showed a difference. This tool directly without any deposition time has a minimal effect or even statistically no effect with the previous water. The research was continued with the duration of deposition. The results of the complete TDS examination by adding the time of deposition are shown in Table 4. Both the table and the graph show that there are varying results from the beginning of the treatment to the end of the treatment. In this treatment, it was shown that there was a decrease in TDS levels, namely, at $24 \mathrm{~h}$ of deposition.

Table 4: One-way ANOVA test results for Fe, TDS, and salinity on a venturi aerator, precipitation, magnetic deposition, sea sand filter, and anion and cation resins in one unit based on time of deposition

\begin{tabular}{|c|c|c|c|c|c|}
\hline & $\begin{array}{l}\text { Sum of } \\
\text { square }\end{array}$ & df & $\begin{array}{l}\text { Square } \\
\text { mean }\end{array}$ & $\mathrm{F}$ & Sig. \\
\hline $\begin{array}{l}\text { Fe treatment with lengthy deposition } \\
\text { Value between groups }\end{array}$ & 826 & 6 & 0.138 & \multirow[t]{3}{*}{786.847} & \multirow[t]{3}{*}{0.000} \\
\hline Value in groups & 0.002 & 14 & 0.000 & & \\
\hline Total & 0.829 & 20 & & & \\
\hline \multicolumn{6}{|l|}{ TDS treatment with lengthy deposition } \\
\hline Value between groups & 2680.952 & 6 & 446.825 & \multirow[t]{3}{*}{64.269} & \multirow[t]{3}{*}{0.000} \\
\hline Value in groups & 97.333 & 14 & 6.952 & & \\
\hline Total & 2778.286 & 20 & & & \\
\hline \multicolumn{6}{|l|}{ Alinity treatment with long deposition } \\
\hline Value between groups & 0.003 & 6 & 0.001 & \multirow[t]{3}{*}{94.394} & \multirow[t]{3}{*}{0.000} \\
\hline Value in groups & 0.000 & 14 & 0.000 & & \\
\hline Total & 0.004 & 20 & & & \\
\hline
\end{tabular}


The results of the ANOVA test of the three parameters showed significant differences, which mean that, in general, the three parameters ( $\mathrm{Fe}$, TDS, and salinity) from the use of these tools based on the duration of deposition have significant differences. The difference between treatments by testing the LSD there was a decrease up to an average of $18 \mathrm{mg} / \mathrm{l}$ or an average percentage of 0.6 , although it was still small compared to the initial figure, this was used as a capital for further treatment in reducing the content TDS. The results of the LSD test showed that the TDS content with a $24 \mathrm{~h}$ deposition time showed significant differences with water before treatment. Judging from the average $24 \mathrm{~h}$ deposition shows a better value. TDSs refer to any mineral, salt, metal, cation, or anion dissolved in water. This includes anything in water other than pure water molecules $\left(\mathrm{H}_{2} \mathrm{O}\right)$ and solid waste.

Solid waste is a particle/substance that is insoluble and does not settle in the water, such as wood grain with a high content of TDS in the drilled well so that this tool has not been able to maximize it to reduce it. This TDS comes from inorganic materials such as rock and air, containing calcium bicarbonate, nitrogen, Fe phosphorus, sulfur, and other minerals. Most of these materials form salts, which are compounds containing both metals and non-metals. Salt usually dissolves in water to form ions. Ions are particles that have a positive or negative charge.

\section{Salinity/CL parameters}

Parameters of salinity/CL of the results in full are contained in Table 5. The table shows the effect of reducing salinity in the treatment of the venturi aerator. When viewed from the one-way ANOVA test as a whole, it shows a difference, both individually and by decreasing the parameters. Furthermore, to see in detail the significant differences between treatments, the LSD test was carried out.

Table 5: One-way ANOVA test results for checking salinity on a venturi aerator, magnetic deposition, filtering sea sand, and anion and cation resins in one unit

\begin{tabular}{llllll}
\hline Salinity analysis results & Sum of squares & df & Square mean & $\mathrm{F}$ & Sig. \\
\hline Value between groups & 0.012 & 7 & 0.002 & 7.855 & 0.000 \\
Value in groups & 0.014 & 64 & 0.000 & & \\
Total & 0.027 & 71 & & & \\
\hline
\end{tabular}

The LSD test results showed no significant difference between the water before treatment and the water after the venturi aerator treatment, although in reality, it showed a reduction in levels of $0.005 \mathrm{mg} / \mathrm{l}$ or a decrease of $0.17 \%$. Because this tool is not optimal in reducing salinity or $\mathrm{CL}$, it is continued with the long deposition treatment. The table shows that the highest decrease occurred at $24 \mathrm{~h}$ deposition, where the reduction in $\mathrm{CL}$ levels was $0.02 \mathrm{mg} / \mathrm{l}$ or $0.68 \%$. The results of the LSD test showed a significant difference, and the average results showed the best number in the $24 \mathrm{~h}$ deposition treatment. Although the decrease is not maximal, this can be used as capital to carry out further experiments. The content of salinity can theoretically be reduced by demineralization to remove all mineral content in the water.

The process of removing ions or minerals dissolved in water can use an ion exchanger. Initially, the ion exchange resin used was from natural materials. However, with the advancement of technology and science, synthetic ion exchange resins are now used, which are made from the copolymerization of certain substances containing dissolving ions as their functional groups. Ion exchange occurs using fluid diffusion in and out of the resin so that ions larger than a specific size cannot react due to a careful selection of the degree of cross-linking of the resin. Another factor influencing resin properties is the type of functional group, which determines the type of ion exchange resin formed and does not affect exchange equilibrium and selectivity. Some studies show a promising process for the removal of heavy metal ions from aqueous solutions involves bonding the metals first to a special bonding agent and then separating the loaded bonding agents from the wastewater stream by separation processes [16]. The applications of genetic engineering in the modification of the microorganisms for increasing the efficiency of the biofiltration process for heavy metals removal have been critically analyzed. The results show that the efficiency of the process can be increased 3- -6-fold with the application of recombinant microbial treatment [17], [18]. Regardless of the promising potentials of the novel formulations, many issues still need to be addressed, including the cost efficiency of the materials, feasibility of scale-up, and the longevity and durability of the novel membranes [19]. Therefore, the search for the optimum operating conditions, fabrication materials, grafting additions, and supplements is ongoing [20].

\section{Conclusion}

Venturi aerator's effect on Fe reduction does not affect TDS and CL of well water. There is an effect of venturi aerator and precipitation with magnets, in one unit on Fe reduction, and does not affect TDS and $\mathrm{CL}$ of well water. There is an effect of venturi aerator, precipitation with magnets, filtration in one unit on $\mathrm{Fe}$ reduction, no effect on TDS, and CL of well water. There is an effect of venturi aerator, precipitation with magnets, filtering, and ion exchange in one unit on $\mathrm{Fe}$ reduction, no effect on TDS, and CL of well water. There is an effect of venturi aerator, magnetic sedimentation, filtration, and ion exchange in one unit on reducing $\mathrm{Fe}$, TDS, and CL of well water during deposition of $24 \mathrm{~h}$. Venturi aerator, magnetic sedimentation, filtration, and ion exchange in one unit against $\mathrm{Fe}$, TDS, and $\mathrm{CL}$ well water are effectively used with $24 \mathrm{~h}$ deposition. 


\section{References}

1. Hasan M. Water and Food Security. Water Resources Information Media. Public Communication Section, Sub-Directorate of Data and Information, Directorate of Development Water Resources Program of the Ministry of Public Works; 2012.

2. Rooswiadji TA. Information Media for Drinking Water and Sanitation. $4^{\text {th }}$ ed. Jakarta, Indonesia; 2012.

3. Chen KL, Mylon SE, Elimelech M. Aggregation kinetics of alginatecoated hematite nanoparticles in monovalent and divalent electrolytes. IImu Teknol Lingkungan. 2006;40(5):1516-23.

4. Alp E, Melching CS. Allocation of supplementary aeration stations in the Chicago waterway system for dissolved oxygen improvement. J Environ Manage. 2011;92(6):1577-83. https:// doi.org/10.1016/j.jenvman.2011.01.014

PMid:21310524

5. Buscaglia GC, Bombardelli FA, García MH. Numerical modeling of large-scale bubble plumes accounting for mass transfer effects. Int J Multiph Flow. 2002;28(11):1763-85. https://doi. org/10.1016/s0301-9322(02)00075-7

6. Zhang Z, Zeng $Y$, Kusiak A. Minimizing pump energy in a wastewater processing plant. Energy. 2002;47(1):505-14. https://doi.org/10.1016/j.energy.2012.08.048

7. Brandt M, Middleton R, Wheale G, Schulting F. Energy efficiency in the water industry, a global research project. Water Pract Technol. 2011;6(2):wpt2011028. https://doi.org/10.2166/ wpt.2011.028

8. Rosso D, Stenstrom MK, Larson LE. Aeration of large-scale municipal wastewater treatment plants: State of the art. Water Sci Technol. 2008;57(7):973-8. https://doi.org/10.2166/ wst.2008.218

PMid:18441421

9. Simpson A, Ranade VV. Modeling hydrodynamic cavitation in venturi: Influence of venturi configuration on inception and extent of cavitation. AIChE J. 2019;65(1):421-33. https://doi. org/10.1002/aic.16411

10. Zahradnik J, Fialova M, Linek V, Sinkule J, Řezníčková $J$, Kaštánek F. Dispersion efficiency of ejector-type gas distributors in different operating modes. Chem Eng Sci. 1997;52(24):4499-510. https://doi.org/10.1016/ s0009-2509(97)00294-7

11. Liu A, Ming J, Ankumah RO. Nitrate contamination in private wells in rural Alabama, United States. Sci Tot Environ. 2005;346(1-3):112-20. https://doi.org/10.1016/j. scitotenv.2004.11.019

PMid:15993687
12. Charles FH, Swartz CH, Badruzzaman AB, Nicole KB, Yu W, Ali A, et al. Groundwater arsenic contamination on the Ganges Delta: Biogeochemistry, hydrology, human perturbations and human suffering on a large scale. C R Geosci. 2005;337(1/2):285-96. https://doi.org/10.1016/j.crte.2004.10.015

13. Ghrefat $H$, Nazzal $Y$, Batayneh A, Zumlot $T$, Zaman $H$, Elawadi $\mathrm{E}$, et al. Geochemical assessment of ground water contamination with special emphasizes on fluoride, a case study from Midyan Basin, North Western Saudi Arabia. Environ Earth Sci. 2014;71:1495-505. https://doi.org/10.1007/ s12665-013-2554-1

14. Karakochuk CD, Murphy HM, Whitfield KC, Barr SI, Vercauteren SM, Talukder A, et al. Elevated levels of iron in groundwater in Prey Veng province in Cambodia: A possible factor contributing to high iron stores in women. J Water Health. 2015;13(2):575-86. https://doi.org/10.2166/wh.2014.297 PMid:26042988

15. Huang B, Li Z, Chen Z, Chen G, Zhang C, Huang J, et al. Study and health risk assessment of the occurrence of iron and manganese in groundwater at the terminal of the Xiangjiang River. Environ Sci Pollut Res Int. 2015;22(24):19912-21. https:// doi.org/10.1007/s11356-015-5230-z PMid:26289336

16. Blöcher C, Dorda J, Mavrov V, Chmiel H, Lazaridis NK, Matis KA. Hybrid flotation-membrane filtration process for the removal of heavy metal ions from wastewater. Water Res. 2003;37(16):4018-26. https://doi.org/10.1016/ S0043-1354(03)00314-2 PMid:12909122

17. Srivastava NK, Majumder CB. Novel biofiltration methods for the treatment of heavy metals from industrial wastewater. J Hazard Mater. 2008;151(1):1-8. https://doi.org/10.1016/j. jhazmat.2007.09.101 PMid:17997034

18. Ahluwalia SS, Goyal D. Microbial and plant derived biomass for removal of heavy metals from wastewater. Bioresour Technol. 2007;98(12):2243-57. https://doi.org/10.1016/j. biortech.2005.12.006

PMid: 16427277

19. Qasim M, Badrelzaman M, Darwish NN, Darwish NA, Hilal N Reverse osmosis desalination: A state-of-the-art review. Desalination. 2019;459:59-104. https://doi.org/10.1016/j. desal.2019.02.008

20. Anis SF, Hashaikeh R, Hilal N. Reverse osmosis pretreatment technologies and future trends: A comprehensive review. Desalination. 2019;452:159-95. https://doi.org/10.1016/j. desal.2018.11.006 